$$
\text { Pontifícia Universidade C Católica }
$$

Ivanilda Maria Figueiredo de Lyra Ferreira

ENTRE GAROTOS, INTOCÁVEIS e BUGRES: o sistema de justiça na consolidação do paradigma de direitos fundamentais.

Tese de Doutorado

Tese apresentada ao Programa de Pósgraduação em Direito da PUC-Rio como requisito parcial para obtenção do título de Doutor em Direito. Aprovada pela Comissão Examinadora abaixo assinada.

Orientador: Prof. José Maria Gomez

Rio de Janeiro

setembro de 2010 


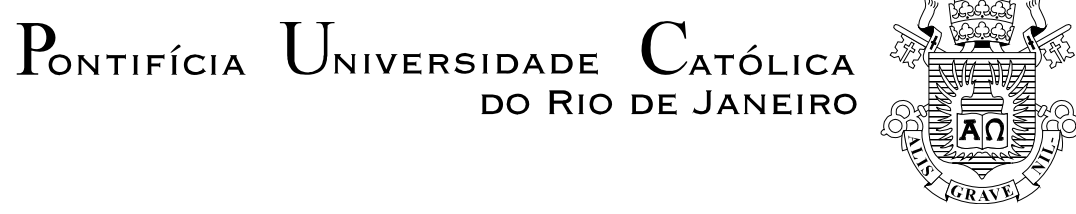

Ivanilda Maria Figueiredo de Lyra Ferreira

\section{ENTRE GAROTOS, INTOCÁVEIS e BUGRES: o sistema de justiça na consolidação do paradigma de direitos fundamentais.}

Tese apresentada ao Programa de Pósgraduação em Direito da PUC-Rio como requisito parcial para obtenção do título de Doutor/a em Direito. Aprovada pela Comissão Examinadora abaixo assinada.

José Maria Gómez

Orientador

Departamento de Direito - PUC-Rio

Eliane Botelho Junqueira Departamento de Direito - PUC-Rio

Flávio Vasconcellos Comim Cambridge/UFRGS

José Ricardo Cunha UERJ/UFRJ

Marcia Nina Bernardes Departamento de Direito - PUC-Rio

Mônica Herz

Vice-Decana de Pós-Graduação do Centro de Ciências Sociais da PUC-Rio

Rio de janeiro, 01 de setembro de 2010. 
Todos os direitos reservados. É proibida a reprodução total ou parcial do trabalho sem autorização da autora, do orientador e da universidade.

Ivanilda Maria Figueiredo de Lyra Ferreira Mestre em Direito Constitucional (UFPE); autora de diversos livros e artigos jurídicos, dentre eles, Políticas Públicas e a Realização dos Direitos Socais (SAFE: 2006). Pesquisadora do Instituto Brasileiro de Análise Socioeconômica (IBASE) Coordenou à pesquisa Acesso à Justiça nos países do IBSA: um diagnóstico, vencedora do III Concurso de Dotações para Pesquisa Ford/luperj e que contou com apoio estrutural/financeiro da PUCRio. Professora Licenciada da Associação Caruaruense de Ensino Superior. Foi bolsista Capes durante os 04 anos de seu doutoramento.

\section{Ficha catalográfica}

Ferreira, Ivanilda Maria Figueiredo de Lyra.

ENTRE GAROTOS, INTOCÁVEIS e BUGRES: o sistema de justiça na consolidação do paradigma de direitos fundamentais / Ivanilda Maria Figueiredo de Lyra Ferreira; orientador:.José Maria Gómez - Rio de Janeiro: PUC, Departamento de Direito.

$259 \mathrm{fl} ; 30 \mathrm{~cm}$

1. Tese (Doutorado) - Pontifícia Universidade Católica do Rio de Janeiro, Departamento de Direito.

Inclui Referências Bibliográficas

1. Direito - Tese 2. sistema de justiça. 3 grupos vulneráveis. 4. direitos fundamentais. 5 . Índia, 6. Brasil e África do Sul (IBAS); 7. acesso à justiça. I. Ferreira, Ivanilda Maria Figueiredo de Lyra. II Goméz, José Maria. III Pontifícia Universidade Católica do Rio de Janeiro. Departamento de Direito. IV Título.

CDD: 340 
À presença primordial da minha família, amigos e amigas. 


\section{Agradecimentos}

Inicio esses agradecimentos reverenciando à figura impar do meu orientador, José Maria Gomez. O Professor Gomez, como costumo chamá-lo, não é "apenas" um acadêmico brilhante, é também um professor e um orientador comprometido através do qual obtive números ensinamentos durante esses quatro anos e do qual me orgulho de ser orientanda. Não posso esquecer do meu orientador de mestrado sem o qual não teria iniciado essa jornada e o qual persisto admirando à distância, Prof. Andreas Krell (UFPE/UFAL).

Nesse percurso me defrontei com inúmeros/as professores/as singulares que no dia-a-dia reiteraram o acerto de minha escolha ao identificar a PUC-Rio como a instituição na qual gostaria de cursar meu doutorado. A pós-graduação stricto sensu da PUC-Rio representa o que todo programa do gênero deveria ser um local no qual o pensamento pode ser exercido sem amarras, permitindo o exercício do livre pensar. Isso só se faz possível pela seriedade de seu corpo docente e de sua gestão acadêmica.

Em meus primeiros dias de doutoramento, envolvi-me voluntariamente na pesquisa sobre acesso à justiça em comunidades de baixa renda liderada pelo Prof. Florian Hoffmann com quem mantive profícua atividade acadêmica mesmo após sua mudança para a London School of Economics e acredito travei forte amizade. Minha admiração pelo modo como realiza seu trabalho e as oportunidades provenientes do aprendizado que sua convivência me proporcionou são imensas.

Foi através das discussões do Grupo de Pesquisa do Prof. Florian que obtive o conhecimento e as idéias para pleitear, e ser aprovada, a dotação individual de pesquisa perante a Ford Foundation e o luperj no III Concurso de Dotação para Pesquisa Ford/IUPERJ como foco na Índia, Brasil e África do Sul. O sucesso dessa empreitada foi surpreendente já que a grande maioria dos/as aprovados/as nos três concursos era professores/as estabelecidos já com o titulo de Doutor/a. Mais surpreendente ainda foram os encontros proporcionados por essa nova pesquisa. Quando da proposição do projeto um grupo de pesquisadores renomados aceitou fazer parte do grupo que debateria de modo analítico-teórico questões essenciais à pesquisa. Intensos foram os debates. Imprescindíveis foram as contribuições. Minha eterna gratidão e reconhecimento a Profa. . Ana Lucia Lyra Tavares, Prof. Florian Hoffmann, Prof. José Maurício Arruti e Prof. Marcia Nina Bernardes. Um agradecimento singular expressando meu reconhecimento, gratidão e eterna amizade é preciso ser feito ao Prof. Rodolfo Noronha por ter acompanhado com total disposição o projeto desde seu planejamento até a redação final.

Imprescindível destacar ainda que o Departamento de Direito da Puc-Rio, dirigido pelo Prof. Adriano Pilatti, reconheceu a importância do projeto tornandoo um dos projetos de pesquisa do seu Núcleo de Direitos Humanos e fornecendo apoio financeiro para que a Profa. Marcia Nina Bernardes pudesse participar da etapa de visitas realizada em Nova Delhi em setembro de 2009. A presença da Profa. Marcia Nina foi decisiva para o sucesso da empreitada. Agradeço enormemente ao Prof. Adriano Pilatti, ao Prof. Firly Filho e a equipe do 
departamento de direito, bem como, a Adrian Sgarbi e Gisele Cittadino, respectivamente, ex-coordenador e atual coordenadora do programa de pósgraduação stricto sensu em direito da PUC-Rio.

Agradeço também a Fundação Ford e o luperj por acreditarem na proposta e permitirem a existência da pesquisa, fornecendo o suporte e o financiamento necessário. Na mesma ocasião em que agradeço a toda a equipe de professores avaliadores III Concurso de Dotação para Pesquisa Ford/luperj, capitaneados pela sempre presente e diligente coordenação da Profa. Maria Regina Lima.

Importante relembrar igualmente os professores e professoras com os quais tive a oportunidade de conviver nas disciplinas do doutoramento, tanto aprendendo: José Ribas Vieira, Nadia Araujo, Celi Scalon (UFRJ) e Jairo Nicolau (luperj).

Não poderia olvidar de louvar e agradecer a presença dos professores e professoras componentes da banca avaliatória: Eliane Junqueira, Flavio Comim, José Maria Gomez, José Ricardo Cunha, Marcia Nina Bernardes e Florian Hoffmann que a distância fez impossível a presença física, mas está presente nas linhas redigidas nesta tese.

Quatro assistentes de pesquisa permaneceram durante os 18 meses realizando o levantamento de dados, tendo colaborado incansável e decisivamente para os resultados aqui apresentados. Sem elas não seria possível, meu muito obrigado a: Camila D’Elia Gabrielle Santos Paz, Maira Ayres Torres e Yasmin Renzo. Outros quatro estiveram uma breve participação como assistentes de pesquisa, mas suas contribuições não são esquecidas: Deborah Meira, Ana Luisa Dáu e Jônatas de Assis Alves e Winnie Hagemeyer. Winnie acompanhou-me ainda no levantamento final de dados para a tese e na revisão do texto.

Uma jornada acadêmica não se desenvolve apenas no campo profissional, é preciso um alicerce no qual se firmar e ao qual recorrer nas horas de fragilidade tão constantes neste percurso. Meu alicerce é representado pela minha família. Minha mãe, Zalitéa, minhas adoradas irmãs Manahiá, Marcia e Sueli, meu irmão Wladi. Minha fofíssima e inteligentíssima sobrinha, Hannah. Não pára por aí, serão sempre lembrados e estão comigo em força, exemplo e energia: meu pai, Luiz Emundo, meu avô Armando, minha avó, Ivanilda, minha madrinha Shewa e a tão saudosa "mãe de criação" Aia. Estes não se foram, pois vivem em meu coração.

Tenho a sorte e o privilegio de fazer parte de uma família muito unida a qual amo, admiro e reverencio nestes momento embora me abstenha de falar o nome de cada um/a, poupando as linhas desse agradecimento que já se alonga.

Imprescindível, no entanto, falar ainda dos meus queridos/as amigos/as. Os que há muito me acompanham, Antonio, Tiago, Felipe, Jailda, Carol, Zélia, Fabi, Renata, Germana, Geo, Tata e os que alegremente agreguei nessa jornada Diana, Daniel V., Daniel A., Leticia M., Leticia e André, Carol e Rodolfo, Joyce, Aline, Janaina, Ana Maria, Ivi, Ana Lucia, Ricky, Carlos A. e Vivi e tantos/as mais que inúmeras linhas ainda seriam requeridas. 
Como é bom ter o quê agradecer. Como é imprescindível ter a quem agradecer. Muito obrigada a todos e todas que estão expressamente nomeados/as e todos os demais que estão em meu coração e minha vida.

Agradeço ainda a Capes e a PUC-Rio pelo apoio financeiro recebido em forma de bolsa durante os quatros anos de curso e a excelente equipe de profissionais administrativos da PUC-Rio: Anderson, Carmem, Marcos e Lindinalva. 


\section{Resumo}

Ferreira, Ivanilda Maria Figueiredo de Lyra; Goméz, José Maria. ENTRE GAROTOS, INTOCÁVEIS e BUGRES: o sistema de justiça na consolidação do paradigma de direitos fundamentais.. Rio de Janeiro, 2010, 259p. Tese de Doutorado - Departamento de Direito, Pontifícia Universidade Católica do Rio de Janeiro.

Os direitos fundamentais são a base de sustentação dos estados democráticos de direito. No entanto, a efetivação dos direitos não ocorre de modo equitativo em todas as sociedades que os proclamam, nem tampouco para todas as pessoas dentro de cada uma delas. A cisão entre direitos civis e políticos de um lado e dhesca's (direitos humanos econômicos, sociais, culturais e ambientais) de outro contraria a própria essência desses direitos, assim como, é uma afronta a normativa internacional que enumera entre suas propriedades a indivisibilidade, interdependência e inter-relação. Por isso, minha proposta é repensar a interconexão entre os direitos fundamentais mediante um substrato teórico capaz de tornar esses princípios mais claros e operativos e levando em consideração a desigualdade no desfrute dos direitos e as raízes dessa márepartição. Assim, uni debates da teoria da capacitação apresentada por Amartya Sen e Marta Nussbaum às tensões sociais identificadas por Nancy Fraser. Além disso, dentro das inúmeras arenas através da quais é possível se empreender a busca pela realização destes direitos busquei o foco na contribuição do sistema de justiça a esse processo. Para tanto, precisei destacar que o sistema de justiça não age sozinho. Ele é parte de uma rede que nomeei Sistema de Garantia de Direitos Fundamentais (SGDF) a qual se constitui na articulação e integração das funções estatais (administração pública, órgãos do legislativo e órgãos do Judiciário) nos três planos federativos, com a sociedade civil organizada e os cidadãos de modo individual ou através de grupos de interesse Embora tenha ressaltado que o SGDF estrutura-se por matéria e não através dos sujeitos, destaquei que o recorte epistemológico dessa tese enfoca os grupos historicamente credores de direitos em três sociedades, a Indiana, a Brasileira, e a Sulafricana. Tais grupos foram escolhidos por serem eles não apenas os mais carentes no desfrute de direitos, mas também no acesso ao sistema de justiça. Os três eixos são interligados, mas o sistema de justiça tem atuação protagônica no eixo da defesa. Nele analisei a atuação das Cortes Constitucionais da Índia, Brasil e África do Sul na realização destes direitos para aquelas pessoas com déficit histórico significativo de acesso a direitos fundamentais. Os dados provenientes da Índia e da África do Sul foram utilizados com o intuito de obter um olhar mais inspirado para o contexto brasileiro. O intuito não era comparar os países, mas valorizar o intercambio de experiência entre países do sul há tantas vivências similares ainda que originadas de contextos históricos, sociais e jurídicos diversos. A constatação de que o acesso dos grupos credores de direitos ao Supremo Tribunal Federal persiste bastante deficitário, mesmo ante o significativo esforço desta Corte em julgar um número imenso de processos fez com que fossem delineadas duas propostas com clara inspiração no contexto sulafricano e indiano: o acesso direto a Corte Constitucional e a instituição de uma nova forma de julgamento dos direitos sociais, condizentes com seu caráter de normas-base do estado de direito contemporâneo.

\section{Palavras-chave}

sistema de justiça; grupos vulneráveis; direitos fundamentais; Índia, Brasil e África do Sul (IBAS); acesso à justiça. 


\section{Abstract}

Ferreira, Ivanilda Maria Figueiredo de Lyra; Goméz, José Maria(advisor). AMONG BOYS, UNTOUCHABLES AND *BUGRES*: The Judicial System In The Consolidation of Fundamental Rights Paradigm. Rio de Janeiro, 2010, 259p. .Doctoral Thesis - Departamento de Direito, Pontifícia Universidade Católica do Rio de Janeiro.

Fundamental rights are the supporting basis of democratic states that follow the rule of law. The appliance of these rights does not happen in an equal way in all societies that proclaim them, nor to all the people within these societies. The divide between civil and political rights on one hand, and economic, social, cultural, and environmental rights on the other is defended by the very own essence of these rights, and by the principles of the international normative that considers them indivisible, interdependent, and inter-related. Because of that, I proposed that the interconnection between fundamental rights be rethought through a theoretical substrate capable of making these principles clearer and operative and taking into consideration the inequality in the enjoyment of these rights and the root of this unequal division. With that in mind, it unites debates about the capability theory presented by Amartya Sen and Marta Nussbaum to the social tensions identified by Nancy Fraser. Moreover, within the several arenas through which it is possible to search for the effectiveness of these rights I tried to focus on the contribution made by the justice system to this process. For that, I needed to highlight that the justice system does not act alone, it is part of a network that I named Fundamental Rights Assurance System (SGDF), which is formed through the articulation and integration of state functions (public administration, legislative offices, and judiciary offices) in the three federative levels, with organized civil society and citizens in an individual manner or through groups of interest. The SGDF should act through three paths, in favor of the effectiveness of fundamental rights: promotion, defense, and control. Although I have emphasized that the SGDF structures itself materially and not through individuals, I highlighted that the epistemological frame of this thesis focuses on the groups historically denied rights in these three societies due to the fact that they are not only the neediest in the enjoyment of rights, but also in the access to justice. The three axes are interconnected, but the justice system has the main role in the defense field. In such area I have analyzed the role of Constitutional Courts in India, Brazil, and South Africa in the appliance of these rights for those people with a significant historical deficit of access to fundamental rights. The data coming from India and South Africa were used with the intent of obtaining a more inspired insight on the Brazilian context. The intent was not to compare these countries, but value the exchange of experiences among countries in the south with similar issues to face. The conclusion that the access to the Supreme Federal Court by underprivileged groups remains with a large deficit, even with the huge effort the Court makes in judging a large number of cases, lead to the outline of two proposals with clear inspiration in the South African and Indian context: the direct access to a Constitutional Court and the creation a new way to decide about social rights.

\section{Keyword}

judicial system; vulnerable groups; fundamental rights; India, Brazil and South Africa (IBSA); access to justice 


\section{Sumário}

$\begin{array}{ll}\text { Introdução } & 14\end{array}$

$\begin{array}{ll}\text { Metodologia } & 22\end{array}$

1. Uma leitura da teoria da capacitação através do recorte de direitos fundamentais. $\quad 27$

1.1 A teoria da Capacitação como uma Parcial Teoria da Justiça: linhas gerais 27

1.2 Os Conceitos Básicos da Teoria da Capacitação 36

1.2.1 Funcionamentos 36

1.2.2 Capacitações 42

1.2.3 O Indivíduo e o Individualismo 46

1.2.4 Escolha da Vida que as Pessoas têm Razão para Valorizar. 54

1.2.5 Capacidade de Agente 59

2. Os Direitos Humanos/Fundamentais pelas Lentes da Teoria Da Capacitação. 62

2.1 Indivisibilidade, Interdependência e Inter-relação de Direitos Fundamentais e a Teoria da Capacitação. 62

2.2 O Mínimo Existencial e a Teoria da Capacitação. $\quad 79$

3. A Estruturação do Sistema de Justiça e a Realização de Direitos Fundamentais por Grupos com Déficits Históricos de Acesso á Direitos na Índia, Brasil e África Do Sul. 92

3.1 O A Estrutura do Sistema de Justiça nos Países Do IBAS. 92

3.1.1 O Caminho Seguido por Índia, Brasil e África do Sul até a Formação de suas atuais Constituições. $\quad 92$

3.1.2 Como se Estrutura o Sistema de Justiça Indiano? 100

3.1.3 Como se Estrutura o Sistema de Justiça Brasileiro? 106

3.1.4 Como se Estrutura o Sistema de Justiça Sulafricano? 111

3.2 Quais os grupos com defasagem de direitos fundamentais irão representar essa situação na Índia, Brasil e África do Sul? 118 
3.2.1 Um conceito jurídico de vulnerabilidade moldado pelos pressupostos da redistribuição, reconhecimento e representação. 118

3.2.2 Na Índia, os/as dalits. $\quad 120$

3.2.3 No Brasil, os/as índios/as. $\quad 124$

$\begin{array}{ll}3.2 .4 \mathrm{Na} \text { África do Sul, os/as negros/as. } & 127\end{array}$

4. O Sistema de Justiça como parte de um Sistema de Garantia de Direitos Fundamentais. 130

4.1 PROPOSTA 01: Assumir um Sistema de Garantia de Direitos Fundamentais em Prol da Realização Desses Direitos. 130

4.2 PROPOSTA 02: O Acesso Direto à Corte Suprema de Grupos com Defasagens Históricas de Direitos Fundamentais. 149

4.2.1 Os exemplos da Índia e África do Sul: uma breve apresentação. 149

4.2.2 As Possibilidades Atuais de Acesso ao STF e suas Limitações. 159

5. Os Direitos Fundamentais em seu Caráter Prestacional são $\begin{array}{ll}\text { Judicializáveis, mas Precisam de Novos Paradigmas. } & 177\end{array}$

5.1 O Debate sobre a Efetivação Judicial dos Direitos Fundamentais Prestacionais.

5.2 PROPOSTA 03: A ampliação do Dialogo Institucional como Forma de Superação das Barreiras à Realização dos Direitos Fundamentais Prestacionais pela Via Judicial. 


\section{Siglas e Abreviações}

$\begin{array}{ll}\text { ACP } & \text { Ação Civil Pública } \\ \text { ADI } & \text { :Ação Direta de Inconstitucionalidade } \\ \text { ADO: } & \text { Ação de Inconstitucionalidade por Omissão } \\ \text { ADC } & \text { Ação Declaratória de Constitucionalidade } \\ \text { ADPF: } & \text { Arguição de Descumprimento de Preceito } \\ & \text { Fundamental } \\ \text { DF's } & \text { Direitos Fundamentais } \\ \text { DH } & \text { Direitos Humanos } \\ \text { DESCA'S } & \text { Direitos econômicos, sociais, culturais e } \\ & \text { ambientais } \\ \text { Estados Unidos da América } & \text { EUA } \\ \text { IBAS } & \text { Índia, Brasil e África do Sul } \\ \text { IDH } & \text { Índice de Desenvolvimento Humano } \\ \text { IPH } & \text { Índice de Pobreza Humana } \\ \text { MI } & \text { Mandado de Injunção } \\ \text { MS } & \text { Mandado de Segurança } \\ \text { OEA } & \text { Organização dos Estados Americanos } \\ \text { ONU } & \text { Organização das Nações Unidas } \\ \text { PNUD } & \text { Programa das Nações Unidas para o } \\ \text { SGDF } & \text { Desenvolvimento } \\ \text { STF } & \text { Sistema de Garantia de Direitos Fundamentais } \\ \text { STJ } & \text { Supremo Tribunal Federal } \\ \text { STA } & \text { Supremo Tribunal de Justiça } \\ \text { TJ } & \text { Suspensão da Tutela Antecipada } \\ & \\ \text { STibul de Justiça }\end{array}$


"The most potent weapon in the hands of the oppressor is the mind of the oppressed (...) In time, we shall be in a position to bestow on South Africa the greatest possible gift - a more human face." (Steven Bantu Biko, ativista AntiApartheid e fundador do Movimento da Consciência negra naqueles tempos sombrios)

"My final words of advice to you are educate, agitate and organize; have faith in yourself. With justice on our side I do not see how we can lose our battle. The battle to me is a matter of joy. The battle is in the fullest sense spiritual. There is nothing material or social in it. For ours is a battle not for wealth or for power. It is battle for freedom. It is the battle of reclamation of human personality." (B.R. Ambedkar, artífice da Constituição Indiana e ativista pelo fim do sistema de castas) 